\title{
ХАРАКТЕРИСТИКА АДМІНІСТРАТИВНОГО СУДОЧИНСТВА В УМОВАХ РЕФОРМУВАННЯ СУДОВОї СИСТЕМИ УКРАЇНИ
}

\author{
СИДОР Наталія Теодозіївна - здобувач кафедри адміністративного \\ права і процесу, фінансового права, інформаційного права Приватного вищого \\ навчального закладу «Львівський університет бізнесу та права» \\ DOI:10.32782/LAW.2019.3.29 \\ УДК 347.998.85
}

\begin{abstract}
В данной статье рассмотренъ вопросъ развития административного судопроизводства, его изель и приниипъ. Процесс, которьй осуществляется административнълм судом, приобретает значение административного судопроизводства. Цель административного судопроизводства представляет собой воображаемую модель желаемого результата, то, к чему стремятся субгекты судебного процесса, то под целью административного судопроизводства следует понимать защиту прав и законных интересов бизических и юридических лии, государства, обеспечения законности и справедливости при осуществлении правосудия. Отмечено, что административное судопроизводство - это форма позивного правосудия, которая состоит во всестороннем, полном, объективном рассмотрении и решении административньли судами в стадийном порядке.

Ключевъе слова: административное судопроизводство, судъ, приничивь, субъекты, цели, задачи, защита прав.
\end{abstract}

\section{Постановка проблеми}

КАС України визначає адміністративне судочинство як діяльність адміністративних судів щодо розгляду і вирішення адміністративних справ у порядку, встановленому Кодексом адміністративного судочинства (пункт 4 частини 1 статті 3) [1].

О. Андруневчин вважає, що процес, який здійснюється адміністративним судом, набуває значення адміністративного судочинства. Змістом адміністративного су- дочинства $є$ втілена у форму правових відносин діяльність суду, а також інших учасників процесу, спрямована на вирішення завдань адміністративного судочинства у галузі публічно-правових відносин, шляхом реалізації наданих прав та обов'язків. Адміністративне судочинство є складовою адміністративної юстиції, а вона, своєю чергою, - складовою адміністративного процесу [2, c. $80-81$ ].

\section{Стан дослідження проблеми}

Безумовно питання розвитку адміністративного судочинства та відповідного законодавства не залишалися поза увагою учених (В. Матвійчук, О. Хар, І. Коліушко, Н. Александрова, А. Комзюк, Р. Мельник, В. Бевзенко, О. Кузьменко, С. Курінний, Т. Гуржій, М. Міхеєнко, С. Харитонова, О. Харитонова тощо), проте у численних працях досліджувалися лише загальні питання адміністративного процесуального феномена, зокрема зміст і сутність адміністративного судочинства, його принципи і завдання.

Виклад основного матеріалу

Становлення України як правової європейської держави, в якій надійно захищаються та гарантуються права та свободи людини органічно пов'язано з формуванням та ефективною діяльністю системи адміністративної юстиції. Характеризуючи адміністративне судочинство як невід'ємний елемент більш загальної системи захисту прав людини необхідно привернути увагу до принци- 


\section{Дискусіі, обговорення, актуально}

пів, особливостей їх застосування та завдання адміністративного судочинства.

Розгорнуте визначення поняття «адміністративне судочинство» дає у дисертаційній роботі А. Руденко. На його думку, яку також підтримує і О. Андруневчин, адміністративне судочинство - це форма позивного здійснення правосуддя, яка полягає у всебічному, повному, об'єктивному розгляді та вирішенні адміністративними судами в стадійному порядку, визначеному нормами Кодексу адміністративного судочинства України, адміністративно-правових спорів, що виникають між фізичними та юридичними особами з одного боку та суб'єктом владних повноважень (органом державної влади, органом місцевого самоврядування, їх посадовими і службовими особами) - 3 іншого, 3 метою захисту прав та свобод фізичних осіб, прав і законних інтересів юридичних осіб, здійснення контролю у сфері публічно-правових відносин [3, с. 28].

Відповідно до пункту 5 частини 1 статті 3 КАС України зміст адміністративного процесу складають правовідносини, що виникають під час здійснення адміністративного судочинства.

Слід відзначити, що становлення галузі адміністративного права України, в якому відбулося теоретичне формулювання терміну «адміністративний процес» відбувалося ще до прийняття КАС України у 2005 році та подальшого становлення системи адміністративного судочинства 3 метою судового вирішення адміністративних спорів.

Мета судочинства становить уявну модель бажаного результату, те, до чого прагнуть суб' єкти судового процесу, то під метою адміністративного судочинства слід розуміти захист прав і законних інтересів фізичних та юридичних осіб, держави, забезпечення законності та справедливості при здійсненні правосуддя. Мета розкривається через завдання [5, с. 6].

Згідно із ч. 1 ст. 2 КАСУ завданням адміністративного судочинства $є$ захист прав, свобод та інтересів фізичних осіб, прав та інтересів юридичних осіб у сфері публічно-правових відносин від порушень з боку органів державної влади, органів місцевого самоврядування, їхніх посадових і служ- бових осіб, інших суб'єктів при здійсненні ними владних управлінських функцій на основі законодавства, в тому числі на виконання делегованих повноважень шляхом справедливого, неупередженого та своєчасного розгляду адміністративних справ. До адміністративних судів можуть бути оскаржені будь-які рішення, дії чи бездіяльність суб'єктів владних повноважень, крім випадків, коли щодо таких рішень, дій чи бездіяльності Конституцією чи законами України встановлено інший порядок судового провадження.

На думку В. Башкатової і О. Світличного, головним завданням вітчизняного адміністративного судочинства, має бути захист природних прав громадян від порушень 3 боку органів публічної влади, їх посадових осіб, які здійснюють владні функції відповідно до чинного законодавства [4, с. 19].

Основним змістом практики правозахисної діяльності адміністративних судів виступає забезпечення відновлення, охорони прав фізичних та юридичних осіб, у разі їх порушень у публічно-правових відносинах, сутність, ознаки та класифікаційні види яких не $є$ ще поки що на належному рівні дослідженими у вітчизняній юридичній науці, проте це питання має велике значення як теоретичне, так і практичне, оскільки безпосередньо пов'язано 3 обранням особою належного суду для захисту тих чи інших своїх прав, порушених чи незабезпечених у відносинах із суб'єктами владних повноважень, а отже й $з$ досягненням завдань оперативності та дієвості судочинства.

Національна концепція адміністративного судового захисту виходить із забезпеченості ним як публічних, так і приватних (визначених відповідно публічним та приватним правом) суб'єктивних прав фізичних осіб, коли допускається їх порушення або обмеження в публічно-правових відносинах суб'єктами владних повноважень (ч. 1 ст. 2 КАСУ). В адміністративному судочинстві захищаються більшість політичних, соціальних прав і свобод громадян України, а також чимале коло економічних, особистих й духовних суб'єктивних правових можливостей людини, визначених нормативно-правовими актами України, реалізація 
яких відбувається у відносинах $з$ органами державної влади та органами місцевого самоврядування, або які зазнають обмежень (порушень) в роботі останньої чи їі посадових чи службових осіб [6, с. 161]. Це свідчить про те, що адміністративна юстиція в Україні 6 спеціальним незалежним правовим інститутом, покликаним урегульовувати, неупереджено розв'язувати спори між державою та громадянським суспільством (його конкретними членами). Зазначене між тим, не виключає виконання адміністративними судами й функції гаранта законності під час державного регулювання економіки, неприпустимості необгрунтованого втручання органів державної влади та органів місцевого самоврядування у сферу вільного ринкового господарювання.

Отже, адміністративне судочинство, як процесуальна діяльність, пов’язується саме iз «розглядом і вирішенням адміністративних справ», що вказує на процесуальну сторону правосуддя в адміністративних справах, характеризуючи таким чином сам його процес, спрямований на розв'язання публічно-правового спору, а також захист прав та інтересів фізичних та юридичних осіб від порушень з боку суб'єктів владних повноважень, якщо таке порушення мало місце.

3 огляду на те, що відповідно до п. 4 ч. 1 ст. 3 КАСУ адміністративне судочинство визначено саме як діяльність адміністративних судів щодо розгляду і вирішення адміністративних справ, тобто вирішення фактично означає усунення публічно-правового конфлікту між фізичною чи юридичною особою та суб'єктом владних повноважень, коли порушене право відновлено чи захищено в інший спосіб, що забезпечує ефективне поновлення в правах або справедливу компенсацію шкоди, або ж коли суд владно підтвердить відсутність між сторонами спірних матеріальних правовідносин і відсутність у позивача права, за захистом якого він звернувся до адміністративного суду, або ж за наявності спірних матеріальних правовідносин дійде висновку про незаконність чи недоведеність позовних вимог позивача.

Переходячи до розгляду принципів адміністративного судочинства, варто сказати, що вони будучи основоположними засадами, ідеями, в яких відображені якісні особливості, певні специфічні властивості, що закріплені в нормах права і які відображають структуру адміністративного судочинства, стан та перспективи його розвитку, спрямовані на захист прав, свобод і інтересів фізичних осіб, прав та інтересів юридичних осіб у сфері публічно-правових відносин від порушень з боку суб'єктів владних повноважень.

Також принципи адміністративного судочинства закріплено, окрім КАС України, у Конституції України, Конвенції про захист прав людини і основоположних свобод та інших міжнародних договорах, згоду на обов’язковість яких надано Верховною Радою України.

Згідно зі ст. 129 Конституції України основними засадами судочинства є: 1) законність; 2) рівність усіх учасників судового процесу перед законом і судом; 3) забезпечення доведеності вини; 4) змагальність сторін та свобода в наданні ними суду своїх доказів і у доведенні перед судом їх переконливості; 5) підтримання державного обвинувачення в суді прокурором; 6) забезпечення обвинуваченому права на захист; 7) гласність судового процесу та його повне фіксування технічними засобами; 8) забезпечення апеляційного та касаційного оскарження рішення суду, крім випадків, встановлених законом; 9) обов'язковість рішень суду. Відповідно до ст. 7 КАСУ принципами здійснення правосуддя в адміністративних судах є: 1) верховенство права; 2) законність; 3) рівність усіх учасників адміністративного процесу перед законом і судом; 4) змагальність сторін, диспозитивність та офіційне з'ясування всіх обставин у справі; 5) гласність і відкритість адміністративного процесу; 6) забезпечення апеляційного та касаційного оскарження рішень адміністративного суду, крім випадків, установлених цим Кодексом; 7) обов'язковість судових рішень [1].

Також необхідно зазначити, що в принципах адміністративного судочинства відображені його основні риси та визначено структуру, засади побудови, логіка розміщення положень, що повною мірою дозво- 


\section{Дискусії, обговорення, актуально}

ляє зрозуміти його суть та значення, сприяє правильному застосуванню норм адміністративного судочинства. Принципи адміністративного судочинства слід розглядати у тісному взаємозв'язку між собою, які у структурованому вигляді становлять єдину систему, взаємодоповнюють один одного та розкриваються через зміст іншого.

Як слушно наголошує С. Бондарчук, принципи сприяють правильному пізнанню та застосуванню адміністративно-процесуальних норм, є основою для законодавчої практики, підготовки, розробки і прийняття відповідних їм за змістом правових норм та подальшого їх удосконалення, характеризують суть та значення права як регулятора суспільних відносин у галузі здійснення правосуддя в адміністративних справах, його соціальну цінність. До характерних властивостей принципів адміністративного судочинства відносить: а) ідейну спрямованість - в основі принципів закладена певна ідея, яка $є$ передумовою їх виникнення i обумовлюється соціально-правовими чинниками суспільного життя; б) формальну визначеність - принципи знаходять свій прояв у нормі права через їх текстуальне нормативне закріплення в КАСУ у вигляді окремої статті; в) демократичність - принципи адміністративного процесу є елементом людської культури, цінностями ідеологічного порядку, таких як правова держава, громадянське суспільство, рівність, незалежність і свобода; г) дієвість - принципи адміністративного судочинства враховуватися на всіх стадіях адміністративного процесу, у всіх видах проваджень в адміністративних справах; д) автономність - зміст одного принципу не повинен дублювати змісту інших принципів адміністративного процесу; е) системність - принципи складають певну сукупність, що перебуває у відношеннях i зв’язках між собою, та формують відповідну цілісність та єдність [7, с. 15].

Принципи адміністративного судочинства можна класифікувати за такими критеріями: 1) за сферою поширення - загальноправові, галузеві, міжгалузеві; 2) за способом нормативного закріплення - принципи, закріплені у Конституції України або у законодавчих нормативно-правових актах і прин- ципи, які реалізуються в судовій практиці і виводяться із положень законодавства про адміністративне судочинство; 3) за об'єктом впливу - принципи, які визначають процесуально-правову діяльність адміністративного суду і принципи, які визначають процесуальну діяльність осіб, які беруть участь у справі (сторін, третіх осіб, представників сторін і третіх осіб); 4) за предметом правового регулювання: а) принципи організації правосуддя (судоустрою і судочинства), а також функціональні (принципи процесуальної діяльності - судочинства); б) принципи, які визначають зміст процесуальної діяльності (офіційне з'ясування всіх обставин справи, диспозитивність, змагальність тощо); в) принципи, які визначають процесуальну форму виконання процесуальних дій (гласність, відкритість). Запропонована класифікація дозволяє уникнути протиріч у термінології і дозволяє належним чином сприймати особливості оновленого адміністративно-процесуального законодавства [8, с. 407].

\section{Висновки}

Підсумовуючи викладене, необхідно зазначити, що принципи як основні правила, вимоги, засади щодо здійснення адміністративного судочинства в Україні поєднані в єдину систему завдяки тому, що кожен з них окремо і всі разом служать єдиній меті - захист прав і свобод людини і громадянина в Україні.

\section{Мiтература}

1. Кодекс адміністративного судочинства України: Закон України від 6 лип. 2005 р. № 2747-IV. Відомості Верховної Ради Украйни. 2005. № № 35-36, 37. Ст. 446.

2. Андруневчин О. М. Суб'єкти адміністративного судочинства України: [дис. канд. юрид. наук: 12.00.07]. Аьвів, 2012. $231 \mathrm{c}$.

3. Руденко А. В. Адміністративне судочинство: становлення та розвиток: [дис. канд. юрид. наук: 12.00.07]. Х., 2006. 209 с.

4. Башкатова В. В., Світличний О. П. Роль адміністративного права України у захисті прав і законних інтересів людини і громадянина: [монографія]. К., 2016. 203 с. 


\begin{tabular}{|c|}
\hline 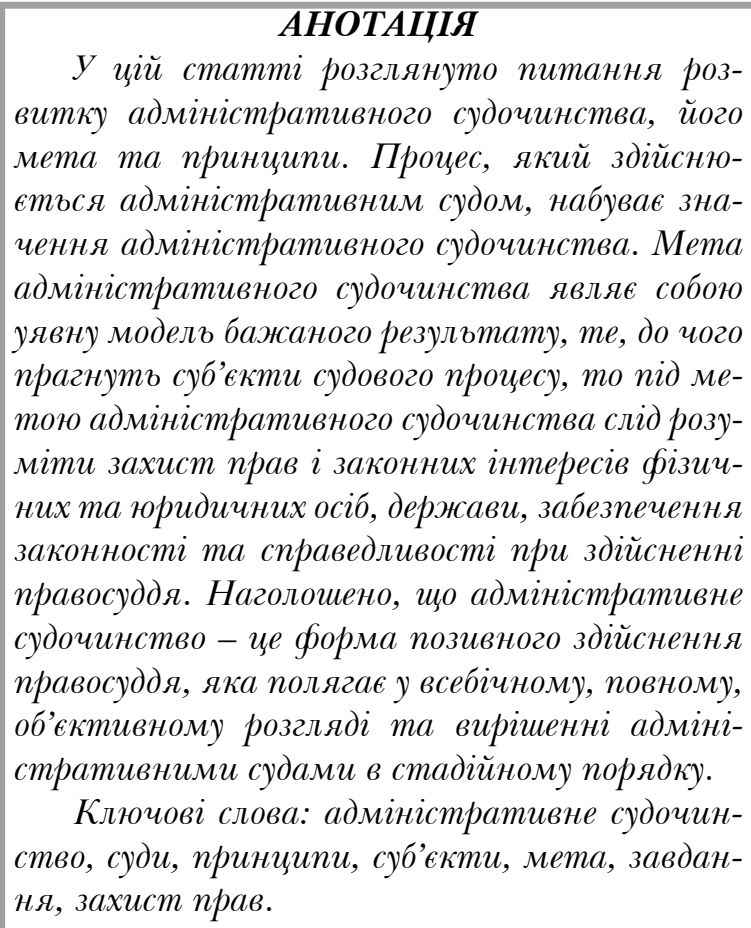 \\
\hline
\end{tabular}

5. Кузьменко А. І. Треті особи в адміністративному процесі.: автореф. дис. на здобуття наук. ступеня канд. юрид. наук: спец. 12.00.07. «Адміністративне право та процес; фінансове право; інформаційне право». К.: Нац. ун-т біоресурсів і природокористування України, 2017. 22 с.

6. Константий О. В. Види прав і свобод фізичних осіб, які захищаються в національній системі судового контролю за публічною
The article deals with issues of development of administrative justice, its purpose and principles. The process, which is carried out by an administrative court, acquires the meaning of administrative proceedings. The purpose of administrative legal proceedings is an imaginary model of the desired result, what the subjects of the trial seek to achieve, then the purpose of administrative legal proceedings should be understood as the protection of the rights and legitimate interests of individuals and legal entities, the state, the provision of legality and justice in the administration of justice. It is stressed that administrative judicial proceedings are a form of call enforcement of justice, which is a comprehensive, complete, objective review and decision by administrative courts in a staggered manner.

Key words: administrative justice, courts, principles, subjects, purpose, tasks, protection of rights.

адміністрацією. Вісник Вищої ради юстищй. 2012. № 3 (11). С. 161-173.

7. Бондарчук С. А. Принципи адміністративного судочинства України: автореф. дис. ... канд. юрид. наук: 12.00.07. Харк. нац. ун-т внутр. справ. Х., 2011. 18 с.

8. Потапенко С. В. Система принципів адміністративного процесу України та проблеми їх класифікації. Форум права. 2010. № 2. C. 403-408 URL: http://www.nbuv.gov. ua/e-journals/FP/2010-2/10pcvpik.pdf. 